DOI https://doi.org/10.30525/978-9934-588-92-1-6

\title{
ДЕРЖАВА I ПРОСТІР В КОНТЕКСТІ ЮРИДИЧНИХ ХАРАКТЕРИСТИК ТЕРИТОРІЇ
}

\author{
Докаш О. Ю. \\ доктор політичних наук, доцент, \\ викладач \\ Фахового коледжу \\ Чернівецького національного університету імені Юрія Федьковича \\ м. Чернівиі, Україна
}

Відзначаючи, що збройна агресія Російської Федерації (далі - РФ) розпочалася 3 неоголошених $\mathrm{i}$ прихованих вторгнень на територію України підрозділів збройних сил та інших силових відомств Російської Федерації, а також шляхом організації та підтримки терористичної діяльності, та беручи до уваги, що РФ чинить злочин агресії проти України та здійснює тимчасову окупацію частини іiі території за допомогою збройних формувань РФ, що складаються 3 регулярних з'єднань і підрозділів, підпорядкованих Міністерству оборони РФ, підрозділів та спеціальних формувань, підпорядкованих іншим силовим відомствам РФ, їхніх радників, інструкторів та іррегулярних незаконних збройних формувань, озброєних банд та груп найманців, створених, підпорядкованих, керованих та фінансованих РФ, а також за допомогою окупаційної адміністрації РФ, яку складають іï державні органи i структури, функціонально відповідальні за управління тимчасово окупованими територіями України, та підконтрольні Російській Федерації самопроголошені органи, які узурпували виконання владних функцій на тимчасово окупованих територіях України [3], вважаємо актуальність запропонованої тематики дослідження беззаперечною.

Поняття держави є дуже багатогранним. За К. Марксом, це особливий механізм, при використанні якого визначений соціальний клас (класи) стає в суспільстві політично пануючим. Отже, вихідним в аналізі держави і пов'язаних 3 нею відносин є поняття влади. Влада - це суспільні відносини, що характеризується здатністю і можливістю однієї людини або групи осіб домагатися здійснення своєї волі іншими людьми, групами людей, цілими народами і державами. Будь-яка спільність людей припускає відносини влади - підпорядкування, від родини, дружньої компанії до етнічної спільності і міждержавних об'єднань. В організованому суспільстві влада виступає як колективна сила. Вершиною соціального розвитку стала політична влада панування 
визначеної групи людей (еліти) над усім суспільством, яка характеризується використанням у випадку непокори насильницьких примусових засобів. Політична влада здійснюється через різноманітні політичні інститути, що формуються в ході розвитку людства, насамперед через механізми держави, партійні системи. Відносини й інститути, пов'язані з функціонуванням політичної влади в суспільстві, складають у своїй сукупності політичну систему. В сучасних міжнародних відносинах механізмом здійснення політичної влади все більше виступають міжнародні організації.

Територія $є$ матеріальною базою існування держави та визначає простір, на який поширюється їі суверенітет і влада [7, с. 56]. Оскільки територія $є$ просторовими межами здійснення державної влади, вона закономірно асоціюється 3 силою або вразливістю держави. Проте територія - не просто простір 3 характерними специфічними просторовими критеріями.

Юридично значимими характеристиками території є розміри (загальна площа); довжина $з$ півночі на південь і зі сходу на захід; компактність; географічне положення, у т.ч. наявність рік і виходу до моря; чисельність і густота населення, розподіл населення по території; кліматичні умови; особливості ландшафту; характер надр та їхньої розробки; характер кордонів (оформлені й фактичні, природні або встановлені); характер прилягаючих територій (державні або міжнародні); період існування [4, с. 18]. Не випадково головним показником території, що вирізняє їі вид, був та залишається правовий режим (або механізм здійснення державної влади), що існує на ній [6, с. 185].

Поняття «простір» і «територія» не є синонімами. Простір містить у собі як власне фізичний простір (територію), так і його географічне поле (географічні взаємозв'язки). Якщо фізичний простір може характеризуватися дискретністю (переривчастістю), то географічному полю властива континуальність (безперервність). Іншими словами, територія виступає не тільки як державна територія, тобто як суспільна, юридична категорія, але й як природне географічне середовище, в якому існує людське суспільство. Нині, як і в минулому, формулу держави в своїй єдності утворюють три поняття: «територія», «державна влада», «населення». Поєднання населення і державної влади народжує феномен визначеного типу суспільства, а вся тріада утворює державу й означає те, що верховна державна влада поширюється на всю дану територію і на всіх людей, що складають іï населення. У випадку вчинення дій, спрямованих на порушення цієї триєдиності, зазіхань на верховенство державної влади, держава має право і зобов'язана забезпечити безумовне підпорядкування своїм розпорядженням. 
Правове закріплення основних положень цієї формули відображується здебільшого в основних законах держав. До прикладу, в ст. 2 Конституції України зазначено, що суверенітет України поширюється на всю її територію. Україна $є$ унітарною державою. Територія України в межах існуючого кордону є цілісною і недоторканною [1]. Україна неухильно проводить політику миру, виступає за зміцнення безпеки народів України виходячи із принципів непорушності державних кордонів, які є відображенням територіальної цілісності, політичної та економічної незалежності, суверенітету та єдності України. Державний кордон України є недоторканним. Будь-які порушення його рішуче припиняються [2].

Наведені положення презентують юридичний стрижень універсального поняття території. В даному контексті територія $\epsilon$ не тільки просторовими межами функціонування суспільства, певною основою існування соціального організму, але й свого роду політичним, економічним і культурним простором, межами здійснення влади всередині країни і межами, за яких держава виступає як зовнішня сила.

Територія - це категорія, що сформувалася історично в тісному зв'язку 3 такими категоріями, як держава i нація. Французький державознавець Л.Дюгі відзначав, що «колективність може бути державою тільки тоді, коли вона осіла на території з визначеними кордонами. Може існувати цілісна соціальна група, в ній може виникнути навіть політична влада, але ця колективність, дійшовши навіть до політичної диференціації, не утворює держави» [5, с. 128]. Держава передбачає територію як частину державної організації. Іншими словами, територія як частина земного простору являє собою необхідну природну умову існування держави, матеріальну основу життя організованого в державу суспільства.

Відзначимо, що феномен фіксації населення на визначеній території (седентаризм) ще в додержавні часи став основою нової соціальної організації, в якій людські співтовариства диференціювалися за територіальним критерієм, що заміняє колишній критерій кровного споріднення. Однак більшого значення територіальний критерій набуває тільки при переході від родового суспільства до держави. Сама держава зароджується в період, коли етноси (народи), нації, певні групи, зв'язок у рамках яких ще грунтується на кровно-племінних основах, починають відокремлювати себе від інших не тільки за ознакою кровного споріднення, спільного правителя, але й за принципом приналежності до тієї території, яку вони займають. Кровний поділ спочатку доповнюється, а потім змінюється територіальним поділом. Отже, основною ознакою державної території $є$ верховенство на конкретній території відповідної державної влади. 
Аналізуючи формально-юридичні властивості території держави, можна виділити такі аспекти: без дозволу владного апарату держави жодна інша влада не має права здійснювати на ній своє панування; всі держави, що знаходяться в межах території, громадяни (піддані), а також інші особи (за винятком осіб, що володіють дипломатичним імунітетом) підлеглі владі держави і їі законам.

Управління державою може здійснюватися лише в просторових межах іiі території. Дію нормативних розпоряджень держави виправдано розглядати як процес існування права в часі, у просторі i серед широкого кола осіб. Тільки тут, використовуючи свою владу, вона може безперешкодно в повному обсязі управляти людьми, і в першу чергу своїми громадянами. Особливі випадки (територія посольств, консульств) лише підтверджують правило. Державність як така тісно пов'язана 3 територіальними ресурсами, вона не може існувати без чітко або умовно обмеженої території. При цьому державна влада поширюється на всю без винятку територію держави: на всі сухопутні, водні й повітряні простори, що знаходяться під юрисдикцією держави, а також об'єкти з державною символікою.

Забезпечення цілісності і недоторканності державної території досягається єдиною державною політикою, довгостроковими і короткостроковими програмами, системою заходів економічного, політичного, організаційного й іншого характеру, адекватних до життєво важливих інтересів особистості, суспільства і держави. Стійкість розвитку, а разом 3 нею і незалежність держави, прямо залежить від цілісності іiі територіальних кордонів.

\section{Література:}

1. Конституція України: Закон України від 28 червня 1996 p. № 254к/96-BP / Верховна Рада України. URL: https: //zakon.rada.gov.ua/ laws/show/254k/96-вр

2. Про державний кордон України: Закон України від 04.11.1991 p. № 1777-XII / Верховна Рада України. URL: https://zakon.rada.gov.ua/laws/ show/1777-12 (дата звернення: 26.10.2020).

3. Про особливості державної політики із забезпечення державного суверенітету України на тимчасово окупованих територіях у Донецькій та Луганській областях: Закон Украӥни від 18.01.2018 р. № 2268-VIII / Верховна Рада України. URL: https://zakon.rada.gov.ua/laws/show/2268-19 (дата звернення:26.10.2020).

4. Долматов І.В. Просторове буття сучасної держави : дис. ... канд. юр. наук : спец. 12.00.01 «Теорія та історія держави і права; історія політичних і правових учень». Одеса, 2009. 22 с. 
5. Дюгі Л. Конституційне право: Загальна теорія держави. Репринт / Передмова Ю.М. Оборотова. Одеса: Юридична література, 2005. 1008 с.

6. Паламарчук В. Теоретико-правові основи розуміння державної території України. Підприсмництво, господарство і право. 2017. № 1. C. $182-186$.

7. Шкабаро В.М., Ященко В.М. Територія як ключова ознака держави та іiі характеристики. Вісник Дніпропетровського університету імені Альфреда Нобеля. Серія «Юридична науки». 2015. № 2(7). С. 56-61.

DOI https://doi.org/10.30525/978-9934-588-92-1-7

\title{
ІСТОРИКО-ПРАВОВІ АСПЕКТИ ФОРМУВАННЯ СПЕЦІАЛЬНОГО ЗАКОНОДАВСТВА У СФЕРІ НАЦІОНАЛЬНОЇ БЕЗПЕКИ УКРАЇНИ
}

\author{
Доронін І. М. \\ кандидат юридични наук, дочент, \\ завідувач науково-дослідної лабораторії \\ Науково-дослідного інституту інформатики і права \\ Національної академії правових наук України \\ м. Київ, Украӥна
}

Становлення законодавства у сфері національної безпеки та оборони в Україні розвивалось за певними періодами, що включає відповідний етап, який характеризує організацію та впровадження відповідної моделі забезпечення національної безпеки. Мова йде про ухвалення уперше спеціального законодавчого акту в цій сфері - Закону України «Про основи національної безпеки в Україні» від 19.06.2003 p.

Підгрунтям для ухвалення законодавчого акту були вимоги реформування системи забезпечення національної безпеки, що випливали із прийняттям Конституції України та побудовою відповідної системи державної влади на основі конституційних приписів. До цього часу організація системи забезпечення національної безпеки України грунтувалась на положеннях Концепції (основ державної політики), схваленою постановою Верховної Ради України від 16.01.1997 р. № 3/97. Зазначений акт відображав відповідні стратегічні настанови, що були в подальшому реалізовані у побудові відповідної організаційно-правової моделі. Насамперед мова йшла про 